\title{
MYŚL POLITYCZNA LEGIONU MLODYCH - AKADEMICKIEGO ZWIĄZKU PRACY DLA PAŃSTWA. WPROWADZENIE DO TEMATU
}

\begin{abstract}
Legion Młodych (LM) był młodzieżową organizacją piłsudczykowską powstałą w 1930 r. Dotychczas nie doczekał się monografii, co czyni badania naukowe pionierskimi. Nieznana pozostaje nie tylko historia związku, ale i jego oryginalna, a zarazem kontrowersyjna myśl polityczna. Młodolegioniści, począwszy od pierwszej deklaracji ideowej z 1930 r., na piedestale postawili ,ideę państwową” i państwo, któremu podporządkowali pozostałe elementy porządku społecznego. Rozwój myśli zależał przy tym od komendanta głównego i składu osobowego Komendy Głównej. W latach 1930-1932 przeważały hasła umiarkowane sprowadzające się do kontynuacji i rozwinięcia idei legionowej Józefa Piłsudskiego. Wraz ze wzrostem wpływów grupy Henryka Dembińskiego z Wilna poglądy polityczne LM ulegały radykalizacji, co znalazło odzwierciedlenie w drugiej deklaracji ideowej z 1932 r. Przyjęte na II Kongresie założenia ponownie czyniły myśla przewodnią państwo, ale młodolegioniści głosili także postulat zorganizowania narodu według hierarchii i dyscypliny, budowy państwa pracą i bronienia krwią, tworzenia elity, którą miał stanowić żołnierz i człowiek pracy. Największymi wartościami stać się miały krew i trud. Myśl państwowa miała zostać zespolona z polskim światem pracy w celu przebudowy gospodarczej, społecznej i politycznej.

Realizując założenia ideowe ojca-kreatora Adama Skwarczyńskiego, myślano także o symbiozie marksizmu z syndykalizmem, której amalgamat stałby się fundamentem państwa uspołecznionego. Domagano się ponadto likwidacji ustroju parlamentarnego opierajacego się na fikcjach teoretycznych i przekształcenia psychiki społeczeństwa w myśl nowej etyki pracy. W polityce zagranicznej celem miały być zorganizowanie współżycia i współpracy narodów na obszarze międzymorza bałtycko-czarnomorskiego oraz rozbudowa marynarki wojennej i floty handlowej.

W następnej fazie rozwoju myśl polityczna się radykalizowała w zakresie zagadnień gospodarczych. Młodolegioniści żądali m.in. wprowadzenia gospodarki trójdzielnej (indywidualnej, uspołecznionej, państwowej), zakazu napływu kapitałów obcych, ingerencji państwa $\mathrm{w}$ obroty handlowe $\mathrm{z}$ zagranicą, zniesienia tajemnicy gospodarczej, czy też przebudowy ustroju rolnego. Oficjalnie jednak LM popierał działania rządowe. Kolejnym ważnym dokumentem, który ma istotne znaczenie dla analizy myśli politycznej LM, była trzecia deklaracja ideowa z 1935 r., w której złagodzeniu uległy postanowienia poprzedniej. Zniknęły m.in. zapisy o całkowitym upaństwowieniu gospodarki i przeciwstawieniu się instytucji Kościoła katolickiego na rzecz częściowego upaństwowienia i dążenia do zapewnienia każdemu obywatelowi jak najdalej posuniętej wolności sumienia i tolerancji. Legionowi Młodych nie udało się zrealizować deklarowanych założeń ideowych w praktyce, ale jego myśl polityczna miała wpływ na założenia deklaracji ideowo-politycznej Obozu Zjednoczenia Narodowego, co pozwala na konstatację, że - wbrew krytycznym ocenom - nie była ona bezwartościową paplaniną akademików.
\end{abstract}

\footnotetext{
${ }^{1}$ Dr hab. Marek Sioma, Instytut Historii Uniwersytetu Marii Curie-Skłodowskiej w Lublinie, pl. M. Curie-Skłodowskiej 5, 20-031 Lublin, tel. 608535 399, e-mail: marek_sioma@ poczta.onet.pl
} 
Słowa kluczowe: Legion Młodych, organizacje młodzieżowe, obóz piłsudczykowski, myśl polityczna, II Rzeczpospolita

Legion Młodych (LM) był organizacją polityczną ${ }^{2}$, chociaż jego działacze woleli określenie społeczno-wychowawcza. Powstał 13 lutego 1930 r. w Warszawie z inspiracji starszego pokolenia piłsudczyków - pułkowników ${ }^{3}$, choć członkowie twierdzili, że z samorzutnej potrzeby młodych, ideowych zwolenników Józefa Piłsudskiego ${ }^{4}$. W dniu narodzin pierwszy organ prasowy LM pisał: „Wyszliśmy Pierwszą Kadrową zrodzoną w Wolnej Polsce na podbój serc i umysłów młodzieży. Skończył się okres spotkań i poszukiwań, rozpoczął się czas nieustannego, codziennego, uciążliwego marszu pod szczytnym sztandarem Pracy dla Państwa".

Motywacją do działania była chęć ujęcia w pewną, logiczną całość młodego pokolenia, które nie mogło wziąć, ze względu na wiek, udziału w walkach o niepodległość ${ }^{6}$, a więc uzyskać legitymacji do rządzenia w państwie. Młodzi chcieli sami o sobie decydować ${ }^{7}$, ale uwzględniając ówczesną sytuację otrzymali wsparcie i opiekę seniorów, którzy mieli nie tylko czuwać nad poprawnością ideową nowej formacji, ale i zapewniać swym autorytetem przychylność struktur państwa na poszczególnych jego szczeblach $^{8}$. Szczególnie ważne okazało się wsparcie Janusza Jędrzejewicza, Bogusława

${ }^{2}$ W październiku 1933 r. Zbigniew Zapasiewicz, komendant główny LM, w Memoriale w sprawie Legionu Młodych przesłanym Waleremu Sławkowi pisał, że był on organizacją młodzieżową o „wybitnie politycznym charakterze [...] do fanatyzmu niemal uznającą ideologię państwową". Zob. Archiwum Akt Nowych (dalej: AAN), Bezpartyjny Blok Współpracy z Rządem (dalej: BBWR), sygn. 25, k. 3. Zob. Legion Młodych w r. 1933 w oczach własnych, oprac. J. Borkowski, „Pokolenia” 28/4(1969), s. 113.

3 A. Pilch, Studencki ruch polityczny w Polsce w latach 1932-1939, „Zeszyty Naukowe Uniwersytetu Jagiellońskiego” CCXCIX, „Prace historyczne” 1972/37, s. 31.

${ }^{4}$ Idee i myśli Legionu Młodych, Warszawa 1937, s. 3; Ksawery Pruszyński pisał: „Z momentem tym rozpoczął się proces, który ani się dotąd nie skończył, ani ostatecznie sklarował: młode pokolenie, które uznało, że wszelkie idee polityczne niewoli, nawet idea niepodległości, straciły 11 listopada 1918 roku grunt pod nogami, poczęło sobie stwarzać dla nowych warunków nową polityczną koncepcję. Ruch ten zogniskował się na uniwersytetach. [...] Następnie w wytworzeniu dwóch ruchów ideowych młodzieży, które zrywały najzupełniej z wszelkimi ideologiami politycznymi niewoli. Te ruchy ideowe są: Legion Młodych - skłaniający się w miare zmniejszania lub zwiększania swej zależności od BBWR coraz bardziej ku kolektywizmowi sowieckiemu «o treści narodowej», o zapędach antyreligijnych pod forma antyklerykalizmu...”. Zob. K. Pruszyński , Niezadowoleni i entuzjaści. Publicystyka, t. I: 1931-1939, wstęp J. Roszko, wybór tekstów G. Pyka i J. Roszko, Warszawa 1990, s. 135.

${ }^{5}$ W otwarte karty, „Echo Akademickie” (dalej: EA) 1931/5, s. 1.

${ }^{6} \mathrm{~W}$ tym czasie istniały dwie liczące się młodzieżowe organizacje propiłsudczykowskie: Związek Polskiej Młodzieży Demokratycznej i Myśl Mocarstwowa. Powstanie trzeciej - Legionu Młodych było elementem walki o władzę w obozie piłsudczykowskim; próbą zdobycia przyczółka młodzieżowego przez grupę pułkowników. Zob. A. Pilch, Prasa studencka w Polsce 1918-1939. Zarys historyczny. Bibliografia, „Zeszyty Naukowe Uniwersytetu Jagiellońskiego. MI. Prace historyczne" 1990/96, s. 32-33.

${ }^{7} \mathrm{~W}$ pierwszej deklaracji ideowej podkreślano „całkowitą samodzielność i niezależność naszego ruchu". Zob. Deklaracja Ideowa Legionu Młodych. Na granicy pokoleń. Kolumny zwycięstwa, Warszawa 1931, s. 5.

${ }^{8}$ Szerzej o tym: [Aleksander Kawałkowski], Zagadnienie młodzieży w Polsce, [w:] Sanacji kłopoty z młodzieża, oprac. J. Borkowski, „Pokolenia” 1970/2, s. 128. 
Miedzińskiego, Juliusza Ulrycha, Adama Skwarczyńskiego (inicjator powstania LM$^{9}$ ) oraz Józefa Piłsudskiego ${ }^{10}$. Akceptacja przez Marszałka, jedynego członka honorowego, poglądów i działań młodolegionistów, być może powodowana przynależnością do związku jego starszej córki Wandy, oznaczała praktycznie możliwość swobodnej działalności ${ }^{11}$, w tym tworzenia nowatorskich, ale i kontrowersyjnych idei i programów politycznych.

Młodzi chcieli rozpocząć swą polityczną karierę od porozumienia się (poznania ze „starymi”), co miało dać możliwość stworzenia platformy do obopólnego zrozumienia ${ }^{12}$, ale proces ten nie przebiegał w sposób właściwy ${ }^{13}$. Trudno było wypracować jednolitą płaszczyznę współpracy, a ponadto młodzi, nie czekając na konstruktywną konwersację, przystąpili w sierpniu 1930 r. do konkretnych prac politycznych, tworząc ,we wszystkich środowiskach odnośne referaty wyborcze" i przystępując do realnej pracy ${ }^{14}$. Zapowiedzieli przy tym intensywną pracę organizacyjną ${ }^{15}$, której efektem miało być powstanie struktur terenowych w miastach akademickich ${ }^{16}$. „Głównym celem Legionu Młodych - pisał Andrzej Pilch - było bowiem wyparcie przeważających dotąd wpływów młodzieży narodowej z terenu szkół wyższych i zajęcie ich miejsca""17.

Warto dodać, że nakreślony cel był wytyczną kreatorów LM. Natomiast pierwszym „programem politycznym” członków-założycieli była „idea państwowa”, w sytuacji gdy od lata 1929 r. trwał samorzutny proces tworzenia się grup młodzieży akademickiej zorientowanej propaństwowo ,szukających jeszcze po omacku punktu oparcia w pogoni za wielkością myśli i pracy" "18. W grudniu 1929 r. w Warszawie powstała pierwsza deklaracja ideowa, której treścią było hasło „Wszystko dla Potęgi i Wielkości Państwa

\footnotetext{
${ }^{9}$ T. Katelbach, Spowiedź pokolenia, przejrzał, poprawił i posłowiem opatrzył S. Cenckiewicz, Gdańsk 2001, s. 228

${ }^{10}$ B. Żongołłowicz, Dzienniki 1930-1936, oprac. D. Zamoyska, Warszawa 2004, s. 320; Zob. też: Przedstawiciele Legionu Młodych u Marszałka Piłsudskiego, „Kurier Wileński” nr 2281/39(1932), s. 2; Nieco ironicznie pisał o tym Adolf Nowaczyński: „W każdym razie nowi Wileńczycy mają już glejt nietykalności (immunitet), mogą pisać i mówić, co się im podoba żywnie i w wolnej chwili gwiżdżąc na sanacyjnych prawicowców. Jeżeli mocniej gwizdną, może jeszcze Torysi i do nich przyjdą?”. Zob. idem, Plewy i perly, Warszawa 1991, s. 193.

${ }^{11}$ Marszałkowa Piłsudska, gen. Rydz-Śmigły i płk Sławek objęli protektorat nad Legionem Młodych, EA 10 X 1930/1, s. 1.

${ }^{12}$ W. Z., Młodzieży - Ciebie bałamucą. Książka Wojciecha Stpiczyńskiego, EA 10 X 1930/1, s. 2.

${ }^{13}$ Szerzej: M. Sioma, Młodzi contra starzy: Legion Młodych w obozie piłsudczykowskim (1930 1935), [w:] Adaptacja - reforma - stabilizacja. Przestrzeń publiczna we wspótczesnych systemach politycznych, red. T. Koziełło, P. Maj, W. Paruch, Rzeszów 2010, s. 161-175.

${ }^{14}$ Rok walki o lepsze Jutro Polski. Wywiad z Komendantem Głównym Legionu Młodych p. Zbigniewem Zapasiewiczem, EA, 10 X 1930/1, s. 2.

${ }^{15}$ Ibidem, s. 2.

${ }^{16}$ W listopadzie 1930 r. Legion Młodych był częścią składową Bloku Młodzieży Współpracującej z Marszałkiem Piłsudskim, w którego skład wchodziła młodzież akademicka, wiejska i rzemieślnicza w liczbie 200 tys. Zob. Wielki Blok Młodzieży Wspótpracującej z Marszałkiem Pitsudskim, EA, 1 XI 1931/2, s. 1. Taka „konfederacja” organizacji młodzieży uniwersyteckiej wynikała z przekonania, że rozbicie społeczne państwa utrudniało, a nawet uniemożliwiało ,państwo-twórczą pracę, paraliżując najlepsze poczynania". Zob. ibidem.

${ }^{17}$ A. Pilch, Studencki ruch polityczny..., s. 36.

${ }^{18}$ W otwarte karty..., s. 1.
} 
Polskiego"19. Trudno jednakże jednoznacznie stwierdzić, czy tylko takie przesłanieprogram propaństwowa młodzież warszawska mogła zaproponować innym środowiskom akademickim. Wiadomo, że hasło to w roku 1933 Stanisław Garczyński utożsamiał z „pierwszą deklaracją ideową”, którą emisariusz z Warszawy zawiózł do Lwowa, gdzie została przyjęta przez 120 zorganizowanych akademików czekających, jak pisano ex post $\mathrm{w}$ prasie młodolegionowej, na sygnał. Wydaje się jednak mało prawdopodobne (szczególnie w świetle przekazów źródłowych), aby przywołane hasło mogło być pierwszą deklaracją ideową. Bardziej możliwe, że była nią deklaracja programowa zbliżona strukturą do wydanej drukiem w 1931 r. Deklaracji Ideowej Legionu Młodych ${ }^{20}$. Jeśli przyjąć, że tak było, to dysponujemy dokumentem, który pozwala odtworzyć pierwszy polityczny program LM. Przewidywał on rozbudzanie zapału ,dla sprawy Państwa Polskiego", wychowywanie pokoleń uważających za swój trud pracę na rzecz kraju, a za „główny pion sumienia obywatelskiego, poczucie odpowiedzialności za losy Państwa” i ludzi czynu, którzy rozumieliby „doniosłość istnienia Państwa i wyższości obowiązków wobec Niego nad wszelkimi interesami grupowymi i osobistymi”"21. W przekonaniu młodolegionistów ówczesne ruchy i ustroje polityczne (nacjonalizm, parlamentaryzm, demokratyzm, liberalizm i socjalizm) znajdowały się w kryzysie, a komunizm dogorywał. Zrzeszając się pod znakiem honoru i „,sztandarem cnót rycerskich naszych przodków”, członkowie LM deklarowali chęć wyjścia „na spotkanie” nowym czasom i formom życia, dając pierwszeństwo w pracy twórczej prawdom wyższego rzędu (moralnym), których upatrywali w religii ${ }^{22}$. Legion Młodych od początku założył także walkę z Obozem Wielkiej Polski, komunizmem i Centralnym Komitetem Wykonawczym Polskiej Partii Socjalistycznej (PPS), a we własnym obozie z grupą „Przełomu” i grupami siejącymi anarchię w walczącej armii ${ }^{23}$. Ponadto istotna była dla niego rywalizacja, chociaż w innym charakterze: „ze starszym społeczeństwem o należyty stosunek do poczynań naszego pokolenia”, aby być „,przez starsze społeczeństwo zrozumiani, abyśmy my ludzie jutra, nie byli mierzeni miarą wczorajszą, ani naginani zbytnio do potrzeb dnia dzisiejszego"24. Nie bez znaczenia było przy tym głoszenie hasła kontynuacji i rozwinięcia idei legionowej Józefa Piłsudskiego.

Sformułowane w pierwszych dwóch latach działalności założenia okazały się jednakże mało skuteczne, albowiem pod koniec 1931 r. LM liczył w Warszawie, Krakowie, Lwowie, Lublinie i Wilnie zaledwie około 850 członków, czyli niecałe $2 \%$ wszystkich ówczesnych studentów ${ }^{25}$. Rzutowało to na kolejne wydarzenia dotyczące tej formacji. Chodziło przede wszystkim o wzmocnienie jego potencjału intelektualnego w taki sposób, aby mógł skutecznie przeciwstawiać się młodzieży wszechpolskiej. Dlatego też Janusz Jędrzejewicz podjął decyzję o przyciągnięciu do współpracy ,silnej intelektualnie i

\footnotetext{
${ }^{19}$ S. Garczyński, Na podbój serc młodego pokolenia, „Legion Młodych” 1933/1, s. 3.

${ }^{20} \mathrm{Z}$ treści poprzedzającej dwanaście paragrafów deklaracji ideowej wynika, że tekst powstał w momencie, gdy istniał już LM, a więc po 13 II 1930 r. Zob. Deklaracja Ideowa Legionu Młodych..., s. 3.

${ }^{21}$ Ibidem, s. 4.

${ }^{22}$ Ibidem, s. 5-6.

${ }^{23}$ W otwarte karty..., s. 1-2.

${ }^{24}$ Ibidem, s. 2.

${ }^{25}$ A. Pilch, Studencki ruch polityczny..., s. 36.
} 
wpływowej w środowisku studenckim grupy H[enryka] Dembińskiego"26, która w Wilnie skutecznie neutralizowała działania młodzieży narodowej. Szkopuł polegał jednakże na tym, że zarówno Dembiński, jak i jego współpracownicy uzasadnienia swych poglądów poszukiwali „zarówno w katolickiej doktrynie społecznej, jak i w marksizmie"27. Komunizm został oficjalnie uznany za zbrodnię stanu w $1932 \mathrm{r}^{28}$, a więc rok po tym, jak wileńscy młodolegioniści zdążyli na łamach „Słowa” i jego dodatków (,Żagary” i „Wilcze Zęby”) wyeksponować założenia programu, który krytykował ustrój kapitalistyczny oraz „etyczny typ człowieka, którego wychowuje demokracja burżuazyjna"29. Postulowali także „przejęcie przez państwo kierownictwa nad całą produkcją narodową, społeczną kontrolę nad kapitałem, planową gospodarkę, wywłaszczenie obszarników, organizowanie chłopskich spółdzielni wytwórców”" ${ }^{\text {oraz }}$ konieczność powstania państwa pracy zorganizowanej.

Były to poglądy radykalne, które w pewnej mierze znajdowały posłuch we władzach Komendy Głównej LM i u Zbigniewa Zapasiewicza, który jako komendant główny miał nadzieję na stworzenie symbiozy marksizmu z syndykalizmem, jej amalgamat stałby się fundamentem państwa uspołecznionego. Warto dodać, że założenie to korelowało $\mathrm{z}$ przekonaniami Adama Skwarczyńskiego dążącego do stworzenia ideologii, którą obóz piłsudczykowski mógłby przyciągnąć młodzież ${ }^{31}$.

Służyła temu między innymi wydana 19 marca 1932 r. druga deklaracja ideowa, którą uchwalił II ogólnopolski kongres LM w Warszawie. Liczyła piętnaście punktów zawierających swoisty program polityczny. Jego myślą przewodnią było państwo, któremu młodolegioniści podporządkowali pozostałe elementy. Głosili postulat zorganizowania narodu według hierarchii i dyscypliny, budowy państwa pracą i bronienia krwią. Wynikało z tego, że elitą państwa miał być żołnierz i człowiek pracy, a krew i trud były największymi wartościami. Praca w rozumieniu twórców deklaracji była wartością samą w sobie i pierwszym obowiązkiem obywatela Rzeczypospolitej. Miała być także jedynym tytułem do korzystania z „usług społecznych”32. Myśl państwowa miała zostać zespolona $\mathrm{z}$ polskim światem pracy w celu ,przebudowy gospodarczej, społecznej i politycznej”. To ostatnie hasło zostało rozwinięte w punkcie szóstym deklaracji, który głosił, że „Państwo Polskie musi zerwać z niewytrzymującym już próby życia ustrojem gospodarczym, liberalno-kapitalistycznym i przekształcić się w państwo zorganizowanej pracy, rządzone przez zorganizowaną hierarchicznie elitę fachową i prowadzące swą gospodarkę na zasadach planowości. Podstawą przyszłego planu gospodarczego winno być dążenie do osiągnięcia jak największej samodzielności gospodarczej w stosunku do zagranicy” ${ }^{33}$. Dopełniał go następny postulat głoszący, że „Nowy ustrój gospodarczy

\footnotetext{
${ }^{26}$ Ibidem, s. 37.

${ }^{27}$ Ibidem.

${ }^{28}$ Od 1932 r. wraz z wejściem w życie nowego Kodeksu karnego działalność komunistyczna była traktowana jako zbrodnia stanu zagrożona karą od 10 lat pozbawienia wolności do dożywotniego więzienia lub kary śmierci. Zob. M. Jedynak, System kar w partyzanckich szeregach, „Wiedza i Życie. Inne oblicza historii” 2014/2, s. 18.

${ }^{29}$ A. Pilch, Studencki ruch polityczny..., s. 37.

${ }^{30}$ Ibidem, s. 37.

${ }^{31}$ Zob. A. Skwarczyński, Myśli o nowej Polsce, Warszawa 1934.

${ }^{32}$ Ten element deklaracji nie został doprecyzowany.

${ }^{33}$ Deklaracja Ideowa uchwalona przez II Ogólnopolski Kongres Legionu Młodych w Warszawie, dn. 19 marca 1932 r., „Legion Młodych” 1933/1, s. 2.
} 
oprzeć się musi na kontroli Państwa nad produkcją, oraz na przymusowych związkach zawodowych",34.

Ponadto w deklaracji domagano się likwidacji ustroju parlamentarnego opierającego się na fikcjach teoretycznych i przekształcenia ,psychiki społeczeństwa w myśl nowej etyki pracy”. W polityce zagranicznej celem miało być zorganizowanie „współżycia i współpracy narodów" na obszarze międzymorza bałtycko-czarnomorskiego, ale i w obszarze Bałtyku z rozbudową marynarki wojennej i floty handlowej. W polityce wewnętrznej postulowano współpracę bez nienawiści, wierność i lojalność obywateli wobec Polski manifestowana w konieczności obrony granic i ich nietykalności. A także w myśl zasady wolności sumienia deklarowano tworzenie „nowego typu obywatela polskiego", ale w poszanowaniu religii, jako „źródła idealnych pierwiastków ludzkości”. Obywatele i państwo postępować mieli według zasady dotrzymywania słowa, kierując się honorem osobistym i zbiorowym połączonym $z$ honorem pracy ${ }^{35}$.

Należy stwierdzić, że wpływy koncepcji politycznych grupy Dembińskiego są aż nadto widoczne oraz że stały się one (jak też publicystyka ich dotycząca) podstawą do oskarżania LM (szczególnie w Wilnie) o bolszewizm w myśleniu. Dał temu wyraz między innymi Adolf Nowaczyński, nazywając działaczy tego oddziału „wostoczną sanacją"36. Przyczyniły się do tego poglądy wypowiedziane przez prominentnych działaczy młodolegionowych z Wilna. Stefan Jędrychowski twierdził wręcz, że: „1. Polska, jako kraj, stanowiący kolonię kapitału zagranicznego, głównie francuskiego, miałaby zerwać $\mathrm{z}$ dotychczasowym układem stosunków, 2. Polska winna by oprzeć swój byt gospodarczy o współpracę gospodarczą z Rosją tzn. Związkiem Radzieckim, 3. Taka współpraca wymagałaby zrzucenia z Polski deprawujących więzów obecnego ustroju gospodarczego" ${ }^{, 37}$. Na te wynurzenia zareagowała redakcja „Robotnika” dowodząc, że jeśli LM był przeciwnikiem socjalistycznej koncepcji przebudowy ustroju społecznopolitycznego i kulturalnego, to $\mathrm{w}$ rzeczywistości domagał się Polski przynależnej do sowieckiego obszaru gospodarczego w roli „równouprawnionego współczynnika, zorganizowanego na sposób podobny, niejako przystosowany" ${ }^{38}$. W kontekście asymilacji gospodarczej z ZSRS nastąpiłaby jednak asymilacja państwowo-polityczna, czego Jędrychowski nie dostrzegał ${ }^{39}$. Nowaczyński spuentował twórców określeniami: „wileńskie komsomolce” i „komsomalcy”. Natomiast Nathan Szwalbe z „Naszego Przeglądu” stwierdził, że najbardziej wysunięte na Wschód Wilno „stało się ośrodkiem nowej lewicy polskiej, odważnie szukającej samodzielnych dróg i haseł"40. Andrzej Pilch zauważył natomiast, że ,założenia ideowe Legionu Młodych w tym czasie pod wpływem różnych środowisk stanowiły próbę pogodzenia elementów postępowego programu $\mathrm{w}$

\footnotetext{
${ }^{34}$ Ibidem

${ }^{35}$ Ibidem.

${ }^{36}$ A. Nowaczyński, Plewy i..., s. 184.

${ }^{37}$ Cyt. za: ibidem, s. 186.

${ }^{38}$ Cyt. za: ibidem.

${ }^{39}$ Cyt. za: ibidem; Inaczej postrzegał to zagadnienie Ksawery Pruszyński, który stwierdził, że Stefan Jędrychowski w 1932 r. podczas odczytu w Wilnie przekonywał, że Polska powinna była przyłączyć się do ZSRS i stać się bratnią republiką Ukrainy, Azerbejdżanu i Kazachstanu. Zob. K. Pruszyński, Promienie ultra czerwone, [w:] idem, Powrót do Soplicowa. Publicystyka, t. II: 1940 1948, wybór tekstów G. Pyka i J. Roszko, Warszawa 1990, s. 122.

${ }^{40}$ Cyt. za: A. Nowaczyński, Plewy i..., s. 188, podkreślenie w oryginale.
} 
zakresie reform społecznych z pewnymi postulatami ustrojowo-politycznymi, których wzór zawierała zarówno doktryna społeczna Kościoła katolickiego, jak i ustrój faszystowski" ${ }^{41}$. Krytykę deklaracji przeprowadził natomiast Związek Polskiej Młodzieży Demokratycznej (ZPMD), podkreślając różnice w programie organizacji konkurującej o wpływy w tej samej grupie docelowej (młodzież akademicka, inteligencja pracująca, robotnicy). Uznania nie znalazły korporacjonizm, syndykalizm, zasady: elity zawodowej, skrajnej lewicowości, antyklerykalizmu, czy też idea państwowa w rozumieniu LM postrzegana przez ZPMD jako „faszystowska koncepcja nadrzędności państwa, opierająca

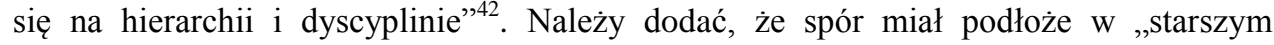
społeczeństwie", gdzie trwała rywalizacja między pułkownikami popierającymi Legion Młodych a naprawiaczami wspierającymi Związek Polskiej Młodzieży Demokratycznej. Głos w dyskusji zabrał także promotor LM w Wilnie z czasów jego początków, Stanisław Mackiewicz (Cat), zwracając uwagę, że kształt myśli politycznej LM był w pewnym sensie pochodną „machnięcia ręką" przez Bezpartyjny Blok Współpracy z Rządem (BBWR) na związek, który postrzegano jako organizację policyjną wykonującą polecenia władzy ${ }^{43}$.

Analizując rozwój myśli i działalności politycznej LM, wypada zauważyć, że w ciągu niespełna 15 miesięcy od momentu jego powstawia nastąpiła krystalizacja poglądów, a także sformułowanie przez Leona Stachórskiego, kolejnego komendanta głównego, przekonania, że LM powinien spełniać trzy zasadnicze warunki: posiadać ideę życiową i odpowiednią strukturę organizacyjną, mieć fanatyków i wodza o wielkim autorytecie moralnym ${ }^{44}$. Nie ulega przy tym wątpliwości, że cała działalność polityczna nastawiona była na realizację tych założeń ${ }^{45}$ oraz że dla młodolegionistów wodzem nadal pozostawał Józef Piłsudski ${ }^{46}$. Warto zauważyć, że założenia programowe zawarte $\mathrm{w}$ drugiej deklaracji ideowej, inaczej niż w większości podobnych tekstów, kwestie ustroju gospodarczego stawiały przed politycznymi ${ }^{47}$. Wiedzie to do przekonania, że przyszły ustrój polityczny miał być pochodną zmian gospodarczych, to jest między innymi rezygnacji z kapitalizmu, i do stwierdzenia, że LM przekroczył bramy i mury uczelni wyższych, kierując swój program do robotników i inteligencji pracującej. Takie zdefiniowanie grupy docelowej spowodowało zmianę taktyki i metod działania, a w konsekwencji konflikty, które narastały między LM a BBWR i „ludźmi sprawującymi opiekę nad organizacją”48. Ich podłożem była również nowa ustawa o szkołach akademickich (15 marca 1933 r.)

\footnotetext{
${ }^{41}$ A. Pilch, Studencki ruch polityczny..., s. 40.

${ }^{42}$ Ibidem, s. 42.

${ }^{43}$ S. Mackiewicz, Ćwierć prawdy o „Legionie Młodych”, „Słowo” 3491/353(1933), s. 1.

${ }^{44}$ A. Nowaczyński, Perly i..., s. 191.

45 Świadczy o tym chociażby zorganizowanie dla działaczy młodolegionowych we Lwowie seminarium politycznego, a w Warszawie seminariów prądów ideowych, politycznego i ekonomicznego. Zob. AAN, Ministerstwo Spraw Wewnętrznych (dalej: MSW), sygn. 856, k. 6, Sprawozdanie kwartalne z życia polskich legalnych zwiąków i stowarzyszeń za okres od 1 stycznia do 31 marca $1933 r$.

${ }^{46}$ K. Moczarski, Sygnat Komendanta, „Państwo Pracy”, 8 X 1933/32, s. 1.

${ }^{47}$ Nie dziwi zatem, że w roku 1934 projekt nowej konstytucji został oceniony jako niewystarczający pod względem zmian ustroju gospodarczego. Zob. J. Kozielewski, Legion Młodych a Konstytucja Styczniowa, [w:] Pod znakiem pracy 1930-1934: jednodniówka, Legion Młodych, Brzeżany 1934, s. 15 .

${ }^{48}$ [Aleksander Kawałkowski], op. cit., s. 128.
} 
zakazująca aktywności politycznej organizacjom ogólnopolskim i międzyuczelnianym na terenie akademickim, odbierająca prawo przynależności do stowarzyszeń uczelnianych absolwentom i wzmacniająca nadzór między innymi nad ich gospodarką. W wypadku LM, który popierał wprowadzenie ustawy ${ }^{49}$, doprowadziło to do wykrystalizowania się przekonania o konieczności rozwinięcia działalności „na szerszej arenie politycznej"

Nie bez racji wydaje się również zwrócenie uwagi na fakt, że największa aktywność polityczna LM przypadła na czasy wielkiego kryzysu gospodarczego, co miało i ten skutek, że ogrom problemów, z którymi mierzył się rząd i BBWR, przesłaniał nieco zagadnienie młodzieży ${ }^{51}$. Dzięki temu istniejące i nowo powstałe organizacje młodzieżowe bardzo szybko upodabniały się do partii politycznych ${ }^{52}$. Tak też w Ministerstwie Wyznań Religijnych i Oświecenia Publicznego (MWRiOP) postrzegano $\mathrm{LM}^{53}$. Należy dodać, że ewolucja ta wyraźnie kolidowała, szczególnie od 1933 r., Z polityką MWRiOP, którego naczelnik Wydziału Polityki Oświatowej Aleksander Kawałkowski postulował, posługując się przykładem LM, uznanie zasady stanowiącej, że „młodzież musi być kierowana, prowadzona, wychowywana [...] i pod żadnym pozorem nie może sama stanowić niezależnego ośrodka dyspozycji wychowawczej”" ${ }^{\text {"5 }}$. O taktyce i ideologii decydować mieli starsi! Młodym pozostawiono sferę wykonawczą.

Narastająca krytyka zmusiła działaczy młodolegionowych do przedyskutowania podstaw programu na III kongresie LM (3-6 maja 1933 r.) w Poznaniu ${ }^{55}$. Bardzo mocno podkreślono tam polską rację stanu jako najważniejsze kryterium w rozwoju i potęgi państwa polskiego ${ }^{56}$. Jednocześnie działacze młodolegionowi rozstrzygnęli, poprzez własne „prawdy ideowe”, sposób ich realizacji. Komendant główny pisał: „Zasady ideologii Legionu Młodych w żadnym więc razie nie mogą być uznane za cele same w sobie, ale za wskazania jedynie właściwych dróg, prowadzących do celu największego,

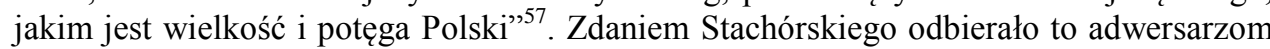
podstawę krytyki dowodzącej, że LM stawał się talmudystyczny i doktrynerski. Ponadto na III kongresie młodolegioniści wyraźnie zdefiniowali wroga, upatrując go w endecji, stronnictwie, które „zapisało się haniebnymi kartami w dziejach Polski"58. Wskazano także młodzież jako grupę, od której należało rozpocząć „deendekację”. Jednocześnie uznając Związek Strzelecki za jedyną organizację mającą prawo prowadzić działalność

\footnotetext{
${ }^{49}$ AAN, MSW, sygn. 856, k. 6, Sprawozdanie kwartalne z życia polskich legalnych związów $i$ stowarzyszeń za okres od 1 stycznia do 31 marca $1933 r$.

${ }^{50}$ [Aleksander Kawałkowski], op. cit., s. 129.

${ }^{51}$ Por. Legion Młodych w r. 1933..., s. 109-125.

52 [Aleksander Kawałkowski], op. cit., s. 120.

33 Ówczesny wiceminister wyznań religijnych i oświecenia publicznego ks. Bronisław Żongołłowicz zapisał w swoim dzienniku pod datą 4 maja 1934 r.: „Od 2-ch lat [Legion Młodych M.S.] wszedł na teren pozaakademicki i stał się stronnictwem politycznym. Operować zaczął demagogią, burzyć zaczął niechęć do starego pokolenia... [Zbigniew] Zapasiewicz wodził rej sam, zdeprawował się i innych zdemoralizował". Zob. B. Żongołłowicz, op. cit., s. 531.

${ }^{54}$ [Aleksander Kawałkowski], op. cit., s. 125.

55 III Ogólnopolski Kongres Legionu Młodych w Poznaniu. Pod znakiem przemian, Legion Młodych"1933/4-5 , s. 12.

${ }^{56}$ L. Stachórski, Oblicze polityczne Legionu Młodych, „Legion Młodych” 1933/4-5, s. 17.

${ }^{57}$ Ibidem.

${ }^{58}$ Ibidem.
} 
wojskową, LM przypisał sobie „teren wychowania obywatelskiego i państwowego w ruchu strzeleckim”, mając nadzieję na „zrozumienie dla powyższej tezy"s9.

Pozostałe elementy myśli politycznej (polityka zagraniczna, mniejszości narodowe) nie uległy zmianom. Radykalizowała się natomiast myśl w zakresie zagadnień gospodarczych. Legion Młodych domagał się bowiem: 1. ograniczenia ustawowego maksimum posiadania indywidualnego (upaństwowienia wielkiej i średniej własności); 2. gospodarki trójdzielnej (indywidualnej, uspołecznionej, państwowej); 3. zakazania napływu kapitałów obcych jako nieliczących się , ,ani ze stroną społeczną, ani gospodarczą procesów bezpośrednich i wtórnych"; 4. daleko posuniętej ingerencji państwa w obroty handlowe z zagranicą; 5. zniesienia tajemnicy gospodarczej; 6. rozwoju sił fachowych; 7. ingerencji państwa $\mathrm{w}$ gospodarkę leśną $\mathrm{i}$ wodną $\mathrm{z}$ dążeniem do „upaństwowienia wielkich obszarów leśnych"; 8. całkowitej przebudowy ustroju rolnego (wywłaszczenie wielkiej własności prywatnej za odszkodowaniem w wysokości maksimum ustawowego posiadania); przymusowej komasacji i melioracji, powstania państwowych gospodarstw wzorcowych, oraz spółdzielczości organizowanej i kontrolowanej przez państwo ${ }^{60}$. Znamienne jest przy tym, że III kongres, próbując uchronić LM przed krytyką za poglądy gospodarcze, stwierdzil, że popierał politykę rządu w tym zakresie, koncentrując swoją uwagę i wysiłki na sprawach ustrojowych i przyszłości ${ }^{61}$.

Tak więc od lata 1933 r. LM, liczący już około 3 tysięcy członków akademików ${ }^{62}$, działał nadal w oparciu na zasadach deklaracji ideowej z 1932 r. zrzeszając nie tylko młodzież o poglądach umiarkowanych, nacjonalistycznych, ale i „Zwolenników

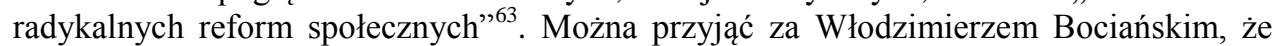
była to organizacja stojąca na gruncie „tzw. nacjonalizmu społecznego o zabarwieniu religijnym i idealistycznym", dla której kult państwa pozostawał świętością, a „przebudowa społeczna nie była celem lecz środkiem, aby mogła istnieć wielka i silna Polska"64. Bardzo mocno natomiast przeciwstawiano się w LM komunizmowi, szczególnie niebezpiecznemu na Kresach Wschodnich ${ }^{65}$.

Hucznie obchodzone czterolecie istnienia Legionu Młodych (18 lutego 1934 r.) nie mogło jednakże przykryć coraz większej krytyki ze strony nie tylko opozycji (endecji, komunistów, Kościoła katolickiego ${ }^{66}$ ), ale i „starych” piłsudczyków, którym zaczynały

\footnotetext{
${ }^{59}$ Ibidem.

${ }^{60}$ III Ogólnopolski Kongres Legionu Młodych..., s. 15.

${ }^{61}$ Ibidem.

${ }^{62}$ E. Kaszuba, System propagandy państwowej obozu rządzacego w Polsce w latach 1926-1939, Toruń 2004, s. 177. W październiku 1933 r. Zbigniew Zapasiewicz w memoriale do Walerego Sławka szacował całkowitą liczbę członków na 18 tys. Zob. AAN, BBWR, sygn. 25, k. 7.

${ }^{63}$ A. Pilch, Studencki ruch polityczny..., s. 52.

${ }^{64}$ Ibidem, s. 52.

${ }^{65}$ AAN, MSW, sygn. 856, k. 29, Sprawozdanie kwartalne z życia polskich legalnych zwiąków $i$ stowarzyszeń za okres od 1/IV do 31.VI. 1933 r.; 3 września 1933 r., podczas II ogólnowołyńskiego zjazdu LM podjęto deklarację, że „Legion Wołyński tępić będzie wszelkie jego (komunizmu) przejawy w życiu politycznym, społecznym i intelektualnym, dążąc do usunięcia poza nawias społeczeństwa tych jednostek, które by w jakiejkolwiek dziedzinie wykonywały destrukcyjny wpływ doktryny komunistycznej”. Zob. ibidem, k. 48, Sprawozdanie kwartalne z życia polskich legalnych zwiazków i stowarzyszeń za okres od 1 lipca do 31 września 1933 r.

${ }^{66}$ Ibidem, sygn. 857, k. 9, Sprawozdanie kwartalne z życia polskich legalnych stowarzyszeń $i$ związów za okres od 1 stycznia do 31 marca 1934 r.
} 
przeszkadzać coraz głośniej i donioślej wybrzmiewające nacjonalizm, radykalizm i samodzielność poglądów. Legion Młodych żądał bowiem „obywatelstwa w Państwie”,67, a ten postulat kolidował $\mathrm{z}$ linią polityczną obozu piłsudczykowskiego ${ }^{68}$, który w połowie 1934 r. zaczął poszukiwać alternatyw dla coraz bardziej podzielonego i wewnętrznie niejednolitego Akademickiego Związku Pracy dla Państwa czuwającego nad rozwojem i działalnością LM na terenie uniwersyteckim ${ }^{69}$. Nie bez znaczenia było przy tym potępienie W lutym 1934 r. LM przez Episkopat Polski, który zarzucił związkowi zwalczanie Kościoła katolickiego, kontestację chrześcijaństwa, propagowanie komunizmu i bolszewizmu oraz wolnej miłości ${ }^{70}$. Komenda Główna LM zareagowała brakiem polemiki i dementi podanych przez Episkopat informacji, podkreślając, że związek nie występował przeciwko Kościołowi jako instytucji religijnej, ale nie godził się na polityczną działalność części kleru, która „,W żadnej płaszczyźnie nie daje się pogodzić z podstawowymi założeniami polskiej racji stanu"71. Nie pomagały także wysiłki i stałe zainteresowanie ze strony premiera Janusza Jędrzejewicza ${ }^{72}$. Młodolegioniści podjęli decyzję o przejściu od „,zdrowych myśli - do realnego ich urzeczywistniania”, gdyż „zatrzymanie się w punkcie decydującym, jakim jest dzień dzisiejszy, może zniszczyć wszystko to, co w ruchu młodolegionowym jest najpiękniejsze - czyn dla dobra świata pracy" ${ }^{\prime 73}$

Oznaczało to, że drogi młodolegionistów i piłsudczyków poczynały się rozchodzić. Powodem było przede wszystkim dążenie do samodzielności, a także coraz wyraźniejsza kontestacja i zniechęcenie do poczynań MWRiOP (Janusza Jędrzejewicza, Aleksandra Kawałkowskiego i Porejki) i jego polityki młodzieżowej ${ }^{74}$. Jej zanegowanie spowodowało serię listów potępiających LM ,zbieranych z gorliwością godną lepszej sprawy”75. Zaistniałą sytuacje próbowała tłumaczyć prorządowa „Gazeta Polska"76, ale ówczesne działania i poglądy polityczne LM zniechęcały seniorów do skutecznego popierania niedawnych faworytów. Frustrację młodolegionistów pogłębiał przy tym napływ do obozu sanacyjnego niedawnych opozycjonistów, elementów ziemiańskich i wielkokapitalistycznych, oraz powstawanie typu, jak sami określali, „piłsudczyka-

\footnotetext{
${ }^{67}$ L. S., Zgrzyty, „Państwo Pracy” 4 III 1934/8, s. 2.

${ }^{68}$ Waldemar Paruch stwierdził, że w pierwszej połowie lat trzydziestych XX w. w obozie piłsudczykowskim „nie zakładano więc realizacji żadnej utopijnej wizji, wywiedzionej bezpośrednio z ideologii, traktowanej dogmatycznie”. Zob. idem, Myśl polityczna obozu pitsudczykowskiego 1926-1939, Lublin 2005, s. 356.

69 Do rozłamu doszło w kwietniu 1934 r., kiedy posłuszeństwo komendantowi głównemu Zbigniewowi Zapasiewiczowi wypowiedział akademicki obwód warszawski i kilkunastoosobowa grupa we Lwowie. Zob. A. Pilch, Studencki ruch polityczny..., s. 53.

${ }^{70}$ Ks. S. Bednarski T.J., A jednak winni!... Prawda o Legionie Młodych, Kraków 1934, s. 6.

${ }^{71}$ AAN, MSW, sygn. 857, k. 10, Sprawozdanie kwartalne z życia polskich legalnych stowarzyszeń $i$ związów za okres od 1 stycznia do 31 marca 1934 r.

${ }^{72}$ B. Żongołłowicz, op. cit., s. 550.

${ }^{73}$ Okres przejściowy, „Legion Młodych” 1934/5-7, s. 18.

${ }^{74}$ Al. Fa., Smutne losy „, genialnej” koncepcji, „Nowe Państwo Pracy” 2 II 1936/1, s. 2; Zdaniem F. Mirzyńskiego popieranie LM przez Janusza Jędrzejewicza stało się podłożem klęski polityki młodzieżowej MWRiOP. Zob. idem, Czy tylko to maja do powiedzenia?, „Kurier Wileński” 9 X 1936/277, s. 1.

${ }^{75}$ T. Horko, Audiatur et altera pars, „Nowe Państwo Pracy” 15 XI 1936/13, s. 3.

${ }^{76}$ Al[eksander] K[awałkowski], Na ideowym starcie, ,Gazeta Polska” 30 VIII 1934/240, s. 3.
} 
endeka”. W ich przekonaniu w obozie piłsudczykowskim było coraz „ciaśniej”, a członkowie LM zaczęli spotykać się z „wrogim spojrzeniem” "77. Oceniali ponadto, że obóz zatracał cechy oddania idei wielkiego, potężnego państwa i podporządkowania zasadzie „Salus Reipublice suprema lex” na rzecz osobistych i grupowych interesów ${ }^{78}$.

Warto zauważyć, że przedstawione fakty były składową walki, jaka rozgrywała się w obozie piłsudczykowskim i LM. W obu przewagę zyskiwali przeciwnicy radykalizowania działań. W LM skutkowało to między innymi zmarginalizowaniem Zbigniewa Zapasiewicza, a następnie jego wydaleniem. W sierpniu 1934 r., po kilkumiesięcznej walce i wyborze na komendanta głównego inż. Witolda Bielskiego, Aleksander Kawałkowski mógł stwierdzić, że „zwyciężył kierunek pracy ideowo-wychowawczej, zgodnej z zasadami, na których oparta jest myśl polityczna naszego obozu"79. Wydaje się, że była to ocena tyleż prawdziwa ${ }^{80}$, co pochopna. Niewątpliwie ,starym” piłsudczykom udało się doprowadzić do załagodzenia wewnętrznych sporów, zmarginalizować elementy nieprzystające do ich ideologii, a nawet ustawić pracę LM na właściwych ideowowychowawczych torach ${ }^{81}$, ale wysiłek ten zniweczył ściśle tajny okólnik Sekretariatu Generalnego BBWR z 5 września 1934 r. określający LM, Myśl Mocarstwową i ZPMD jako organizacje prorządowe, ale jednocześnie nakazujący tymże podporządkowywanie się decyzjom Bloku ${ }^{82}$. Ponadto polecał on przeorganizowanie kół seniorów LM pod kątem lepszego kontaktu każdego ośrodka $\mathrm{z}$ analogicznym szczeblem struktury terytorialnej BBWR i $z$ zadaniem reprezentowania przez koła seniorów pracy i wystąpień zewnętrznych młodolegionistów na danym terenie ${ }^{83}$. Zabraniał ponadto LM prowadzenia działalności wśród młodzież wiejskiej, robotniczej i inteligenckiej, uznając to „za szkodliwe dla ruchu" ${ }^{84}$ (sic!). Okólnik spotkał się z powszechną krytyką, w tym nowego komendanta głównego, Witolda Bielskiego, i większości okręgów (szczególnie krakowskiego i wileńskiego). Miał przy tym różne konsekwencje. Przede wszystkim pogłębił konflikt na tle rozumienia i realizacji dotychczasowych idei (programu

\footnotetext{
${ }^{77}$ W. Zagórski, Ideologia zysku - polityka koniunktury, „Państwo Pracy” 8 IV 1934/13, s. 1 (toż: Ideologia zysku - polityka koniunktury, „Legion Młodych” 1934/5-7, s. 11).

${ }^{78}$ W. Zagórski, op. cit., s. 1.

${ }^{79}$ Al[eksander] K[awałkowski], op. cit., s. 3; AAN, MSW, sygn. 857, k. 111, Sprawozdanie kwartalne z życia polskich legalnych stowarzyszeń i zwiazków za okres od llipca do 30 września 1934 r. W styczniu 1935 r. Ksawery Pruszyński pisał, że rozłam w LM, który zaczął się w maju 1934 r., trwał nadal, a jego powodem były publikowane i omawiane na łamach „Państwa Pracy” tezy ideologii komunistycznej. Zob. idem, Proces przy drzwiach otwartych. „Legion Młodych”czerwona sotnia, „Problemy” 3/4 (1935), s. 2.

${ }^{80}$ Witold Bielski wydał między innymi zarządzenie o ustalaniu linii politycznej LM wobec BBWR, administracji i wszelkich organizacji politycznych wyłącznie przez komendanta głównego, odbierając jednocześnie taki przywilej okręgom i obwodom. Zob. AAN, MSW, sygn. 857, k. 111, Sprawozdanie kwartalne z życia polskich legalnych stowarzyszeń i związków za okres od 1 lipca do 30 września $1934 r$.

${ }^{81} \mathrm{Al}[$ eksander] K[awałkowski], op. cit., s. 3.

82 J. Bieliński, Na marginesie okólnika Bloku, „Państwo Pracy” 9 XII 1934/49, s. 1; Elżbieta Kaszuba uznała LM za „ekspozyturę obozu rządzącego”. Zob. eadem, op. cit., s. 201.

${ }^{83}$ J. Bieliński, op. cit., s. 1.

${ }^{84}$ AAN, MSW, sygn. 857, k. 159, Sprawozdanie kwartalne z życia polskich legalnych stowarzyszeń i związów za okres od 1 października do 31 grudnia 1934 r.; A. Pilch, Studencki ruch polityczny..., s. 55 .
} 
politycznego) między zwolennikami nadrzędności państwa, w którym przebudowa społeczna była jedynie niezbędnym środkiem potęgi kraju, a propagatorami zmian ustroju kapitalistycznego (w dziedzinie społecznej i gospodarczej) jako celu samego w sobie i realizowanego w oparciu na permanentnej walki klas ${ }^{85}$.

Pod koniec grudnia 1934 r., co wynika z referatu komendanta Witolda Bielskiego, LM popierał BBWR, był organizacją nacjonalistyczną, ale nie rasistowską (znamienne, że nie przyjmowano Żydów! ${ }^{86}$ ), nieco faszyzującą, przeciwstawiającą się walce klas, zwalczającą dyktaturę proletariatu, ale negatywnie ustosunkowaną do liberalizmu kapitalistycznego, dążącego do upaństwowienia wielkiego przemysłu, uznającą wartości religii chrześcijańskiej, a co za tym idzie - niedążącą do rozdziału państwa od Kościoła. W tym czasie opowiadał się także za tolerancją religijną, prawami dla mniejszości narodowych, ale asymilacją państwową Ukraińców i Białorusinów, zasadą koncepcji elity zawodowej, eliminacją partii politycznych i zniesieniem demokracji parlamentarnej ${ }^{87}$.

Były to poglądy władz naczelnych LM i większości okręgów terenowych wobec zwierzchników, ale nie oddawały one realnej sytuacji, albowiem w skali kraju nie wszystkie środowiska młodolegionowe popierały Komendę Główną ${ }^{88}$. W grudniu $1934 \mathrm{r}$. Józef Bieliński w obszernym tekście przeanalizował, co prawda, założenia ideowe związku, ale było to uwarunkowane chęcią przypomnienia władzom BBWR kwestii dotychczasowych idei, programu i dokonań. Dodał przy tym, że działaczom LM przestał odpowiadać Blok jako „polityczny konglomerat odcieni ideowych i bezideowych” stojący w wyraźnej sprzeczności z marzeniami młodolegionistów o bezkompromisowej walce o „powszechną sprawiedliwość społeczną i rozbudowę potęgi Państwa”89. W konsekwencji LM stać się miał bezosobową, a więc $\mathrm{i}$ bezprogramową przybudówką BBWR na terenie akademickim. Wywołało to sprzeciw młodolegionistów, którzy jednakże nie zamykając sobie drzwi, dowodzili, że „od współpracy z Blokiem Legion się nie usuwa, ale w granicach dopuszczalnych ideowo (specjalnie w terenie)" ${ }^{\prime 90}$. W ich przekonaniu BBWR miał być blokiem, który mogliby utożsamiać całkowicie $\mathrm{z}$,pojęciem Obozu piłsudczyków" "91. Wyróżniał się szczególnie obwód krakowski, którego działacze prezentowali poglądy dalekie od przedstawionych, opowiadając się między innymi przeciwko nacjonalizmowi, klerykalizmowi i kapitalizmowi, a za walką z burżuazją,

\footnotetext{
${ }^{85}$ Kilka słów prawdy, „Nowe Państwo Pracy”,8 XI 1936/12, s. 1.

${ }^{86}$ W kwestii żydowskiej LM opowiadał się za emigracją do Palestyny, której obszar uważano za najodpowiedniejszy. Zob. Idee i myśli..., s. 22; zob. też: AAN, MSW, sygn. 857, k. 150-161, Sprawozdanie kwartalne z życia polskich legalnych stowarzyszeń $i$ zwiazków za okres od 1 października do 31 grudnia 1934 r.

${ }^{87}$ Cyt. za: A. Pilch, Studencki ruch polityczny..., s. 56. Legion Młodych krytykował ponadto brak programu kolonizacyjnego i niewystarczające rezultaty osadnictwa wojskowego. Zob. Idee $i$ myśli..., s. 17.

${ }^{88}$ Ksawery Pruszyński w styczniu 1935 r. konstatował: „Na tych samych łamach „Państwa Pracy”, w których dla publikacji żołnierzy POW, żołnierzy Legionów nie było miejsca, pokazywały się przez cztery lata dziesiątki $i$ setki artykułów, które były bliźniaczo podobne do obecnej ulotki Komsomołu. Walka klas była tam dogmatem społecznym, Marks prorokiem, kołchozy szczytami cywilizacji”. Zob. idem, Proces przy drzwiach otwartych..., s. 2 [podkreślenia w oryginale].

89 J. Bieliński, op. cit., s. 1-2.

${ }^{90}$ Ibidem, s. 2.

${ }^{91}$ Ibidem.
} 
upaństwowieniem prywatnych środków produkcji i budową ,państwa zorganizowanej pracy" "92. Podobne poglądy prezentowali młodolegioniści w Poznaniu i Wilnie ${ }^{93}$. W tym ostatnim doszło do radykalizacji poglądów, czego wyrazem była zmiana na stanowisku komendanta obwodu akademickiego, na którego wybrano Władysława Rońca, działacza Związku Lewicy Akademickiej. Punktem przełomowym okazała się jednakże odezwa radykalnej opozycji w LM protestująca między innymi przeciwko ,jawnie faszystowskiej polityce Komendy Głównej Legionu Młodych" ${ }^{\text {"94 }}$.

Zachodzące wewnątrz LM procesy przekonują, że od momentu kryzysu, czyli od połowy 1934 r. związek przechodził burzliwą fazę personalno-ideowej reorganizacji, w wyniku której odeszli prawie wszyscy założyciele i czołowi przywódcy ${ }^{95}$, poglądy polityczne uległy modyfikacjom ${ }^{96}$, zlikwidowano miesięcznik „Legion Młodych”, ale nie uzyskano jedności koncepcji i metod dalszej egzystencji. Wiele zależało od konkretnych postaci, które uzyskiwały wpływ na prezentowanie poglądów politycznych danego okręgu. Trudno znaleźć jednoznaczne kryterium stwierdzające, dlaczego okręgi białostocki, wileński, poznański, krakowski, lwowski czy obwód częstochowski były bardziej radykalne w poglądach niż pozostałe. Nie ulega jednak wątpliwości, że w pierwszej połowie 1935 r. nastąpiło zachwianie relacji pomiędzy Komendą Główną w Warszawie a tzw. terenem, którego działacze dążyli do usamodzielnienia się i rozszerzenia obszaru wpływów, co starała się blokować centrala. Środkiem były przy tym hasła radykalizmu i antyklerykalizmu ${ }^{97}$. Pozycję LM w obozie piłsudczykowskim osłabiała także krytyka nowej konstytucji, która w ocenie młodolegionistów nie mogła doprowadzić do powstania państwa pracy zorganizowanej, gdyż nie wprowadzała odpowiedniego ustroju państwa (szczególnie gospodarczego) ${ }^{98}$, oraz liczne rozłamy.

Nie może zatem dziwić, że w kwietniu 1935 r. swoje poparcie wycofali seniorzy LM, a niedawny promotor, Janusz Jędrzejewicz, wypowiedział się nawet za likwidacją $\mathrm{LM}^{99}$. Warto dodać, że działania te skutkowały, zapoczątkowanym jeszcze w roku poprzednim $^{100}$, rozkładem organizacyjnym ${ }^{101}$ mającym swoje odzwierciedlenie między innymi w powstaniu Legionu Młodych Frakcji (LM Frakcja) i upadku „Państwa Pracy”, sztandarowego pisma LM (14 kwietnia 1935 r.). I chociaż młodolegionistom w ciągu

92 E. Mroczek, Btędne koło kapitalizmu, „Nowy Ustrój” 1934/3, s. 6-7; T. Pilc, Oblicze dnia dzisiejszego (I), „Nowy Ustrój” 1934/4, s. 3-4; idem, Oblicze dnia dzisiejszego (II), „Nowy Ustrój” 1934/5; idem, O tzw. katolickiej myśli społecznej, „Nowy Ustrój” 1934-1935/6, s. 7-9.

93 AAN, MSW, sygn. 858, k. 10-11, Sprawozdanie kwartalne z życia polskich legalnych stowarzyszeń i związków za okres od 1 stycznia do 31 marca 1935 r.

${ }^{94} \mathrm{Za}$ : A. Pilch, Studencki ruch polityczny ..., s. 57.

95 K. Pruszyński, Jeśli się załamali, to tym gorzej, [w:] idem, Niezadowoleni $i$ entuzjaści. Publicystyka, t. I: 1931-1939, wybór tekstów G. Pyka, J. Roszko, Warszawa 1990, s. 232.

${ }^{96} \mathrm{~W}$ ankiecie „Dziennika Poznańskiego” z grudnia 1934 r. Włodzimierz Bociański przekonywał, że „u nas [tj. w Legionie Młodych - M.S.] ideologia nie jest narzucona”, a religię określił „piękną rzeczą". Zob. K. Pruszyński, Psychika zespołu mocarstwowców, [w:] idem, Niezadowoleni $i$ entuzjaści..., s. 220.

${ }_{97}$ AAN, MSW, sygn. 858, k. 10, Sprawozdanie kwartalne z życia polskich legalnych stowarzyszeń $i$ zwiąków za okres od 1 stycznia do 31 marca 1935 r.

${ }^{98}$ Ibidem.

${ }^{99}$ F. Mirzyński, op. cit., s. 1.

${ }^{100}$ J. Laskowski, Podziemna zgraja, „Państwo Pracy” 21 X 1934/42, s. 1.

${ }^{101}$ Zob. J. Piotrowski, Niech mówia fakty, „Polskie Państwo Pracy” 9 IV 1935/6, s. 4. 
miesiąca udało się wznowić wydawanie nowego tytułu - „Polskiego Państwa Pracy”, to jego łamy wykorzystywali przede wszystkim do rozliczenia się $\mathrm{z}$ seniorami $\mathrm{i}$ podtrzymania członków w przekonaniu, że LM nie przestał istnieć. Brakowało wyraźnie spokoju na przemyślenie i ewentualny nowy program polityczny. W maju 1935 r. młodolegionowy publicysta podkreślał, że w ciągu pięciu lat istnienia LM nikt nie narzucał mu doktryn i programów, a ,ideologia Legionu wytworzyła się nie jako twór sztuczny, ale jako wyraz radykalnych prądów nurtujących młode pokolenie Piłsudczyków" "102. W tym samym czasie Edmund Grudziński twierdził, że LM pozostawał integralną częścią obozu piłsudczykowskiego z zadaniem krystalizacji myśli i ideologii oraz form pracy zgodnych $z$ wolą jego członków. Widział także konieczność i potrzebę pracy $w$ imię stworzenia państwa pracy zorganizowanej ${ }^{103}$. Opowiadał się za niezależnością myśli, uważając, że idea (ideologia), którą propagował LM, była właściwa dla młodego pokolenia. W jego przekonaniu: ,ideologii naszej ani form pracy nigdy nie da się zaszufladkować do tego czy innego wąskiego odcinka młodzieżowego, do takiego czy innego terenu działania...,"104.

Należy zauważyć, że przekonania te stały się podłożem upadku „potęgi” LM, który „walcząc o byt”, nie przestał jednakże zajmować się kwestiami programowymi. Trzy miesiące po rozłączeniu z obozem piłsudczykowskim, na IV kongresie (28 lipca 1935 r.) w „Legionowie Morskim”105, młodolegioniści uchwalili dziesięć tez, które uznać należy za trzecią deklarację programową. Pokazuje to niewątpliwie siłę intelektualną organizacji, która przechodziła ówcześnie okres wymuszonej dekompozycji, ale i znacznie rozszerzyła własną podstawę personalną. Analiza treści owych tez przekonuje, że zostały one nie tylko znacznie rozbudowane, ale i zmienione w stosunku do deklaracji ideowej z 1932 r. Zniknęły bowiem zapisy o całkowitym upaństwowieniu gospodarki i przeciwstawieniu się instytucji Kościoła katolickiego na rzecz częściowego upaństwowienia i dążenia do zapewnienia każdemu obywatelowi jak najdalej posuniętej wolności sumienia i tolerancji. Tezy ideowe były raczej programem politycznym niż młodzieńczą deklaracją ideową będącą porywem serca ${ }^{106}$. Ponadto przebieg kongresu zaświadcza o sile organizacji (417 delegatów z całego kraju i 200 gości), której członkowie nie ulegli namowom premiera Janusza Jędrzejewicza i nie odeszli z Legionu Młodych.

Na kongresie doszło także do przedstawienia Radzie Głównej LM swych poglądów przez krakowskich młodolegionistów, którzy stwierdzili, że „,zadaniem więc politycznej działalności Legionu Młodych musi być właśnie dążenie do rozbudzenia tej świadomości klasowej inteligencji pracującej drogą stworzenia odpowiednika politycznego dla zawodowego ruchu inteligencji pracującej..."107. W konsekwencji dokonał się podział na LM (pozostał pod kuratelą BBWR) i LM Frakcję, z siedzibą w Krakowie. Pierwszy opowiedział się za programem politycznym realizowanym w myśl dotychczasowych

\footnotetext{
${ }^{102}$ T. Horko, Czy znowu od początku, „Polskie Państwo Pracy” 5 V 1935/1, s. 4.

${ }^{103}$ E. Grudziński, Nasz stosunek do Obozu, „Polskie Państwo Pracy” 5 V 1935/1, s. 2.

${ }^{104}$ Ibidem.

105 Tak nazwano miejsce niedaleko Jastarni na Półwyspie Helskim. Delegaci obradowali w drewnianej szopie przy lampie naftowej. Zob. AAN, MSW, sygn. 858, k. 100, Sprawozdanie kwartalne z życia polskich legalnych stowarzyszeń i zwiazków za okres od 1.VII do 30.IX. $1935 \mathrm{r}$.

${ }^{106}$ Litwinowicz, Kongres zwycięstwa $i$ wytrwania z IV Kongresu L. M. w Legionowie Morskim w dn. 28 lipca r.b., „Polskie Państwo Pracy” 31 VII 1935/12, s. 2.

${ }^{107}$ Kilka słów prawdy..., s. 1.
} 
zasad ideowych, z równoczesnym podporządkowaniem się Edwardowi ŚmigłemuRydzowi, podczas gdy LM Frakcja skłaniała się ku realizacji programu w ramach tzw. Frontu Ludowego $^{108}$, od którego zdecydowanie odciął się nurt główny ${ }^{109}$.

Nowy/stary komendant główny Witold Bielski kilka dni po kongresie pisał, że delegaci skoncentrowali się przede wszystkim na sprawach organizacyjnych i ideologicznych, a nie politycznych. Świadczyło to nie o braku zainteresowania tą problematyką, ale o tym, że ważniejsze dla LM były ówcześnie inne odcinki działalności. Uważał przy tym, że po „wyeliminowaniu zgnilizny [między innymi działaczy okręgu krakowskiego - M.S.], która zagnieździła się dzięki naszej lekkomyślności, jesteśmy organizmem zdrowym i mocnym" ${ }^{\text {"110 }}$. Przyznał sobie przy tym prawo pilnowania, by „krzywda imponderabiliom się nie działa”111, a zakończył przekonaniem, że „Legion Młodych musi być i będzie dynamitem, który rozsadzi więzy marazmu i słabości" "112.

Trudno jednoznacznie stwierdzić, jaką skalę słowa te miały w rzeczywistości, ale faktem pozostaje, że po 31 lipca 1935 r. przestało ukazywać się „Polskie Państwo Pracy”113, a LM znajdował się w „okresie rehabilitacji organizacji” (kwiecień 1935 październik 1936), który był czasem utraty mniej lub bardziej intratnych wpływów, w tym posad przez młodolegionistów ${ }^{114}$, wewnętrznej konsolidacji pod hasłem „Przed nami Polska - legioniści naprzód" ${ }^{\text {"15, }}$ oraz pracy nad pogłębieniem ideologii młodolegionowej ${ }^{116}$.

Wraz z nowym zarządem LM wrócił na scenę publicystyczną w lutym 1936 r., gdy wydano pierwszy numer „Nowego Państwa Pracy”, który ukazał się staraniem działaczy stołecznych Legionu ${ }^{117}$. W ten sposób LM rozpoczął następny, tym razem ostatni, rozdział swojej politycznej działalności. Kolejne wydarzenia przyniosły dalsze podziały i rezygnacje z członkostwa (m.in. komendanta głównego Włodzimierza Bociańskiego w 1937 r.). Dotychczasowi, zasłużeni działacze tworzyli nowe struktury polityczne ${ }^{118}$ lub grupy, które w dużej mierze znajdowały miejsce w Klubach Demokratycznych. Warto podkreślić, że również sam LM zmodyfikował formę działalności, tworząc wspólnie z ZPMD i Centralnym Wydziałem Młodzieży PPS federację pod nazwą Front Młodej

\footnotetext{
${ }^{108}$ Ibidem.

${ }^{109}$ Legion Młodych walczy z „Frontem Ludowym”, „Nowe Państwo Pracy” 27 IX 1936/10, s. 1.

${ }^{110}$ W. Bielski, Legion Młodych, „Polskie Państwo Pracy” 31 VII 1935/12, s. 3.

${ }^{111}$ Ibidem.

112 Ibidem.

${ }^{113}$ Powodem były zawirowania polityczne, które spowodowały między innymi nie tylko odmowę kolportażu wspomnianego pisma, ale i konieczność szukania niezbędnych funduszy. Zob. Od wydawcy, „Polskie Państwo Pracy” 2 II 1936/1, s. 2.

${ }^{114}$ Zdaniem Ksawerego Pruszyńskiego pod koniec 1934 r. sześć tysięcy członków LM miało posady rządowe lub stypendia zagraniczne. Zob. idem, Jeśli się załamali..., s. 233.

${ }^{115}$ Z otwarta przyłbicą. Zwycięstwo ideologii Legionu Młodych, „Nowe Państwo Pracy” 10 X $1936 / 11$, s. 1 .

${ }^{116}$ Kilka słów prawdy..., s. 1 .

117 To oni sfinansowali przedsięwzięcie $\mathrm{z}$ utworzonego przez siebie specjalnego funduszu prasowego. Zob. Od wydawcy..., s. 2.

${ }_{118}$ Mowa przede wszystkim o LM Frakcji oraz Klubie „Maurycy Mochnacki”. Zob. Materiaty do historii Klubów Demokratycznych i Stronnictwa Demokratycznego w latach 1937-1939, wstęp i oprac. L. Chajn, Warszawa 1964, s. 189.
} 
Lewicy Polskiej zakładającą działalność antykapitalistyczną, ale nie komunizującą czy antyrządową ${ }^{119}$.

Był to proces w pewien sposób naturalny, zważywszy chociażby na „niemłodzieżowy” wiek odchodzących, ale i oczyszczający, gdyż w LM pozostawali wyłącznie wyznawcy ,jednej myśli młodolegionowej” koncentrującej się wokół zagadnienia Polski potężnej i sprawiedliwej ${ }^{120}$. Sformułowano zresztą doskonałe hasło: „Naród Polski - to Polski Świat Pracy i Polska Armia. Wszystko, co poza tym - jest poza Narodem”,121. Szczegółowa analiza programu wiedzie przy tym do konstatacji, że zmieniło się rozumienie realizacji przytoczonych haseł, albowiem zrównaniu uległy pojęcia „państwo” i „naród”. Pisano między innymi, że „Polska będzie potężna, gdy Naród zostanie wspaniale zorganizowany militarnie, politycznie i gospodarczo. Gdy Naród będzie czuł się gospodarzem swego Państwa" ${ }^{22}$. Ustrój państwa miał być zatem oparty na warstwach pracujących, nie zaś posiadających, które były zależne od kapitału międzynarodowego. Ten punkt programu był zresztą stałym elementem niezgody, albowiem „starzy” piłsudczycy mieli twierdzić: „My chcemy umrzeć w ustroju kapitalistycznym”, gdy młodolegioniści uważali, że międzynarodowe powiązania kapitałowe wykluczały pełną suwerenność państwa i narodu. Odcinali się również od popierania jakichkolwiek doktryn politycznych (Front Ludowy) wywodzących się z ZSRR albowiem „reprezentują [one] rosyjski imperializm i dlatego są obce polskiemu światu Pracy, polskiemu Narodowi" ${ }^{23}$. Opowiadali się natomiast za oczyszczeniem szeregów polskich ruchów radykalnych z komunistów i Żydów.

Stonowanie retoryki programu politycznego miało różnorakie konsekwencje, ale oceniane głównie negatywnie. Elementy, które świadczyły na rzecz dostosowania się do linii programowej obozu piłsudczykowskiego uznano za objaw słabości, podobnie jak nierozwiązanie się LM po liście seniorów. Jeden z adwersarzy konstatował: „Zaczęto przepraszać zagniewanych seniorów i błagać ich przebaczenia i [prosili o - M.S.] przytulenie do łona. «Legion Młodych» zaparł się swej przeszłości, potępił swoje błędy i winy i błagał o grzechów darowanie" ${ }^{124}$. Natomiast działacze LM Frakcji zarzucali LM odejście od pierwotnej ideologii i programu, co zmusiło prawowitych młodolegionistów do wydania oświadczenia, w którym dowodzili, że „Legion Młodych nie zmienił od chwili powstania swojej ideologii. Tak samo jak i przedtem Legion Młodych jest ruchem, który dąży do przebudowy społecznej i gospodarczej Polski" ${ }^{\prime 25}$.

W zestawieniu z reaktywacją okręgów i obwodów, które „mocą wspólnego entuzjazmu" zaczęły się rozwijać, przechodząc do porządku dziennego nad rozłamami, otrzymuje się obraz organizacji, która pod koniec 1936 r. przezwyciężyła wewnętrzny kryzys i odbudowywała pozycję $\mathrm{w}$ środowisku młodzieży ${ }^{126}$. Przekaz wzmocnił komendant główny Bociański, przekonując, że LM był „organizacją o ściśle określonej

\footnotetext{
${ }^{119}$ AAN, MSW, sygn. 859, k. 4-5, Sprawozdanie pótroczne z życia polskich legalnych stowarzyszeń i zwiazków za okres od 1 stycznia do 30 czerwca 1936 roku.

${ }^{120}$ Z otwarta przytbica..., s. 1.

${ }^{121}$ Hasło Nr 2, „Nowe Państwo Pracy” 27 IX 1936/10, s. 2.

${ }^{122}$ Z otwarta przytbica..., s. 1.

${ }^{123}$ Legion Mlodych walczy..., s. 1.

${ }^{124}$ F. Mirzyński, op. cit., s. 1.

${ }^{125}$ Kilka stów prawdy..., s. 1.

${ }^{126}$ R. Kiersnowski, Pro domu sua, „Nowe Państwo Pracy” 26 XII 1936/18-19, s. 1.
} 
ideologii. Stowarzyszeniem, które za główny cel postawiło sobie samowychowanie się w duchu wskazań Józefa Piłsudskiego. Grupą ludzi powiązanych formą zewnętrzną, która dążyła do sprecyzowania państwowej myśli politycznej"127. Należy dodać opartej na nacjonalizmie i ideologii młodolegionowej.

Przedstawione elementy programu przekonują, że LM w drugiej połowie 1936 r., na gruncie młodzieżowym, torował drogę programowi politycznemu przyszłego Obozu Zjednoczenia Narodowego (OZN), głosząc przekonanie, że nowy polski ruch polityczny powinien opierać się na: 1. podkreślaniu zasług Józefa Piłsudskiego; 2. dobrze pojętym nacjonalizmie; 3. zasadzie sprawiedliwości społecznej; 4. uznaniu Edwarda ŚmigłegoRydza „za wodza Narodu nie tylko w dziedzinie wojskowej [...] ale również w znaczeniu politycznym" ${ }^{28}$. Jeśli uwzględni się ponadto, że działacze LM mieli uczestniczyć w rozmowach z Adamem Kocem na temat powołania do życia (w ramach OZN) organizacji młodzieżowej pod nazwą Związek Młodej Polski (ZMP) ${ }^{129}$, i dodatkowo weźmie się pod uwage, że dokładnie w dniu ogłoszenia deklaracji ideowo-politycznej obozu Adama Koca LM, jako jeden z pierwszych, zgłosił akces do OZN ${ }^{130}$, to wyłania się obraz organizacji, której idee i program korespondowały w pewnej mierze z założeniami deklaracji ideowopolitycznej. Komendant główny LM, organizacji ideowo-wychowawczej, widział przy tym dalszą jej rolę jako wychowawczyni „światłych kierowników polskiego ruchu politycznego" $" 131$.

Przystąpienie do OZN nie oznaczało automatycznej likwidacji LM, który nadal kontynuował działalność „statutową”, starając się odegrać znaczącą rolę na odcinku młodzieżowym. Akces spowodował jednak, że jego pozycja uległa osłabieniu. Ponadto stracił wiele ze swego młodzieńczego zapału. Pozbawiono go także organów prasowych, co praktycznie wyeliminowało szersze możliwości propagowania własnej ideologii. Nie bez znaczenia było także powstanie ZMP, który pod przywództwem mjr Edmunda Galinata monopolizował „odcinek młodzieżowy”. Pomimo to 15 maja 1938 r. w Krakowie odbył się kongres LM, który miał zgromadzić ponad tysiąc (sic!) przedstawicieli młodzieży $\mathrm{z}$ całej Polski. Uchwalona rezolucja głosiła, że związek reprezentował „myśl państwową, pojmowaną realnie i nowocześnie” ${ }^{\text {132 }}$. Była to jednakże ostatnia tak znacząca akcja, której pokłosiem był wyraz jakiejkolwiek myśli politycznej.

Legion Młodych zakończył działalność w grudniu 1938 r., gdy w wyniku połączenia ze Związkiem Polskiej Młodzieży Demokratycznej powstał Legion Młodzieży Polskiej ${ }^{133}$.

\section{LITERATURA}

[1] Al. Fa., Smutne losy ,genialnej” koncepcji, „Nowe Państwo Pracy” 2 II 1936/1.

\footnotetext{
${ }^{127}$ W. Bociański, Czym jest Legion Młodych?, ,Nowe Państwo Pracy” 26 XII 1936/18-19, s. 3. ${ }^{128}$ Ibidem, s. 3.

${ }^{129}$ A. Pilch, Studencki ruch polityczny..., s. 84; Leon Chajn pisał, że ZMP powstał „Z połączenia grup Legionu Młodych, Związku Młodzieży Ludowej oraz Falangi...”. Zob. Materiały do historii Klubów Demokratycznych..., s. 203.

${ }^{130}$ Po oświadczeniu ptk. Koca, „Gazeta Polska” 21 II 1937/53, s. 4; J. P., Konsekwencje dla obozu rzadowego, ,Głos Narodu” 24 II 1937/55, s. 3.

${ }^{131}$ W. Bociański, op. cit., s. 3.

${ }^{132}$ Kongres Legionu Młodych, „Zaczyn” 26 V 1938, s. 5.

${ }^{133}$ E. Kaszuba, op. cit., s. 47.
} 
[2] Archiwum Akt Nowych, Bezpartyjny Blok Współpracy z Rządem, sygn. 25.

[3] Archiwum Akt Nowych, Ministerstwo Spraw Wewnętrznych, sygn. 856, 857, $858,859$.

[4] Bednarski St., A jednak winni!... Prawda o Legionie Młodych, Kraków 1934.

[5] Bieliński J., Na marginesie okólnika Bloku, „Państwo Pracy” 9 XII 1934/49.

[6] Bielski W., Legion Młodych, „Polskie Państwo Pracy” 31 VII 1935/12.

[7] Bociański W., Czym jest Legion Młodych?, „Nowe Państwo Pracy” 26 XII 1936/18-19.

[8] Deklaracja Ideowa Legionu Młodych. Na granicy pokoleń. Kolumny zwycięstwa, Warszawa 1931

[9] Deklaracja Ideowa uchwalona przez II Ogólnopolski Kongres Legionu Młodych w Warszawie, dn. 19 marca 1932 r., „Legion Młodych” 1933/1.

[10]Grudziński E., Nasz stosunek do Obozu, „Polskie Państwo Pracy” 5 V 1935/1.

[11]Idee i myśli Legionu Młodych, Warszawa 1937.

[12]Katelbach T., Spowiedź pokolenia, przejrzał, poprawił i posłowiem opatrzył S. Cenckiewicz, Gdańsk 2001.

[13] Garczyński S., Na podbój serc młodego pokolenia, „Legion Młodych” 1933/1.

[14] Hasło Nr 2, „Nowe Państwo Pracy” 27 IX 1936/10.

[15]Horko T., Audiatur et altera pars, „Nowe Państwo Pracy” 15 XI 1936/13.

[16]Horko T., Czy znowu od początku, „Polskie Państwo Pracy” 5 V 1935/1.

[17]J. P., Konsekwencje dla obozu rządowego, „Głos Narodu” 24 II 1937/55.

[18]Jedynak M., System kar $w$ partyzanckich szeregach, „Wiedza i Życie. Inne oblicza historii" 2014/2.

[19]Kaszuba E., System propagandy państwowej obozu rządzacego w Polsce w latach 1926-1939, Toruń 2004.

[20]K[awałkowski] Al[eksander], Na ideowym starcie, „Gazeta Polska” 30 VIII $1934 / 240$.

[21][Kawałkowski Aleksander], Zagadnienie młodzieży w Polsce, [w:] Sanacji kłopoty z młodzieża, oprac. J. Borkowski, „Pokolenia” 1970/2.

[22] Kiersnowski R., Pro domu sua, „Nowe Państwo Pracy” 26 XII 1936/18-19.

[23]Kilka stów prawdy, „Nowe Państwo Pracy” 8 XI 1936/12.

[24]Kongres Legionu Młodych, „Zaczyn” 26 V 1938.

[25]Kozielewski J., Legion Młodych a Konstytucja Styczniowa, [w:] Pod znakiem pracy 1930-1934: jednodniówka, Legion Młodych, Brzeżany 1934.

[26]Legion Młodych w r. 1933 w oczach własnych, oprac. J. Borkowski, „Pokolenia” 28/4 (1969)

[27]L. S., Zgrzyty, „Państwo Pracy” 4 III 1934/8.

[28]Laskowski J., Podziemna zgraja, „Państwo Pracy” 21 X 1934/42.

[29]Legion Młodych walczy z „Frontem Ludowym”, „Nowe Państwo Pracy” 27 IX 1936/10.

[30]Litwinowicz, Kongres zwycięstwa $i$ wytrwania z IV Kongresu L. M. w Legionowie Morskim w dn. 28 lipca r.b., „Polskie Państwo Pracy” 31 VII 1935/12.

[31]Mackiewicz S., Ćwierć prawdy o „Legionie Młodych”, „Słowo” 3491/353(1933).

[32]Marszałkowa Piłsudska, gen. Rydz-Śmigły i płk Sławek objęli protektorat nad Legionem Młodych, „Echo Akademickie” 10 X 1930/1. 
[33] Materiaty do historii Klubów Demokratycznych i Stronnictwa Demokratycznego w latach 1937-1939, wstęp i oprac. L. Chajn, Warszawa 1964, s. 189.

[34]Mirzyński F., Czy tylko to mają do powiedzenia?, „Kurier Wileński” 9 X $1936 / 277$.

[35]Moczarski K., Sygnał Komendanta, „Państwo Pracy” 8 X 1933/32.

[36]Mroczek E., Błędne koło kapitalizmu, „Nowy Ustrój” 1934/3.

[37]Nowaczyński A., Plewy i perty, Warszawa 1991.

[38] Od wydawcy, „Polskie Państwo Pracy” 2 II 1936/1.

[39]Okres przejściowy, „Legion Młodych” 1934/5-7.

[40]Paruch W., Myśl polityczna obozu pitsudczykowskiego 1926-1939, Lublin 2005.

[41]Pilc T., O tzw. katolickiej myśli społecznej, „Nowy Ustrój” 1934-1935/6.

[42]Pilc T., Oblicze dnia dzisiejszego (I), „Nowy Ustrój” październik 1934/4.

[43]Pilc T., Oblicze dnia dzisiejszego (II), „Nowy Ustrój” listopad 1934/5.

[44]Pilch A., Prasa studencka w Polsce 1918-1939. Zarys historyczny. Bibliografia, „Zeszyty Naukowe Uniwersytetu Jagiellońskiego, MI. Prace historyczne” 1990/96.

[45]Pilch A., Studencki ruch polityczny w Polsce w latach 1932-1939, „Zeszyty Naukowe Uniwersytetu Jagiellońskiego. Prace historyczne” CCXCIX/37 (1972).

[46]Piotrowski J., Niech mówia fakty, „Polskie Państwo Pracy” 9 IV 1935/6.

[47]Po oświadczeniu ptk. Koca, „Gazeta Polska” 21 II 1937/53.

[48]Pruszyński K., Jeśli się załamali, to tym gorzej, [w:] idem, Niezadowoleni $i$ entuzjaści. Publicystyka, t. I: 1931-1939, wybór tekstów G. Pyka, J. Roszko, Warszawa 1990, s. 232.

[49]Pruszyński K., Niezadowoleni i entuzjaści. Publicystyka, t. I: 1931-1939, wstęp J. Roszko, wybór tekstów G. Pyka i J. Roszko, Warszawa 1990, s. 135.

[50]Pruszyński K., Proces przy drzwiach otwartych. „Legion Młodych”-czerwona sotnia, „Problemy” 4/3(1935).

[51]Pruszyński K., Promienie ultra czerwone, [w:] idem, Powrót do Soplicowa. Publicystyka, t. II: 1940-1948, wybór tekstów G. Pyka i J. Roszko, Warszawa 190, s. 122.

[52]Pruszyński K., Psychika zespołu mocarstwowców, [w:] idem, Niezadowoleni $i$ entuzjaści. Publicystyka, t. I: 1931-1939, wybór tekstów G. Pyka, J. Roszko, Warszawa 1990, s. 220.

[53]Przedstawiciele Legionu Młodych u Marszałka Piłsudskiego, „Kurier Wileński” 2281/39(1932).

[54]Rok walki o lepsze Jutro Polski. Wywiad z Komendantem Głównym Legionu Młodych p. Zbigniewem Zapasiewiczem, „Echo Akademickie” 10 X 1930/1.

[55]Sioma M., Młodzi contra starzy: Legion Młodych $w$ obozie pitsudczykowskim (1930-1935), [w:] Adaptacja - reforma - stabilizacja. Przestrzeń publiczna we współczesnych systemach politycznych, red. T. Koziełł, P. Maj, W. Paruch, Rzeszów 2010.

[56]Skwarczyński A., Myśli o nowej Polsce, Warszawa 1934.

[57]Stachórski L., Oblicze polityczne Legionu Młodych, „Legion Młodych” 1933/45.

[58]III Ogólnopolski Kongres Legionu Młodych w Poznaniu. Pod znakiem przemian, Legion Młodych" 1933/4-5.

[59] W otwarte karty, „Echo Akademickie” 1931/5. 
[60]W. Z., Młodzieży - Ciebie bałamuca. Książka Wojciecha Stpiczyńskiego, „Echo Akademickie" 10 X 1930/1.

[61]Wielki Blok Młodzieży Wspótpracującej z Marszałkiem Piłsudskim, „Echo Akademickie" 1 XI 1931/2.

[62]Z otwarta przytbica. Zwycięstwo ideologii Legionu Młodych, „Nowe Państwo Pracy" 10 X 1936/11.

[63]Zagórski Wacław, Ideologia zysku - polityka koniunktury, „Państwo Pracy” 8 IV 1934/13.

[64]Żongołłowicz B., Dzienniki 1930-1936, oprac. D. Zamoyska, Warszawa 2004.

\section{THE POLITICAL THOUGHT OF LEGION OF THE YOUNG - 'WORK FOR THE STATE' ACADEMIC ASSOCIATION. INTRODUCTION TO THE TOPIC}

Legion of the Young (LY) was the youth organization founded in 1930 by the followers of Pilsudski. So far it has not seen the monograph written, which makes the research a pioneering one. Not only is the history of this association obscure, but also its original, yet controversial political thought. Starting from the first ideological declaration of 1930, Young Legionaries put on a pedestal "the idea of the State", subjecting the remaining elements of the social order to the State. The development of this thought was contingent upon the Chief Commander and the composition of the Headquarters. In the years 19301932 moderate slogans prevailed, resolving into the continuation and development of the Józef Pilsudski's idea of the legion. Along with the rise of the influence of Henry Dembiński from Vilnius, the political ideas of LY underwent radicalization, which was reflected in the second ideological declaration of 1932. Assumptions adopted at the Second Congress made the State the keynote issue again, but Young Legionaries also preached the demand to organize a nation according to the hierarchy and discipline, building the State by hard work and defending it with blood, the creation of the elite which was to be formed of the soldiers and the working men. The blood and toil were to become the highest values. The idea of the State was to be united with the Polish world of work in order to reconstruct the economic, social and political order.

Putting into practice the ideological assumptions of their father-creator Adam Skwarczyński, they also thought about the symbiotic relationship between Marxism and syndicalism, the amalgam of which would become the foundation of the socialized state. Furthermore, they called for the liquidation of a parliamentary system based on theoretical fictions and transformation of the psyche of society under the new work ethic. In the foreign policy the objective was to organize the coexistence and cooperation of nations in the BalticBlack Sea Intermarium and the expansion of naval and merchant fleets.

The next phase of the development of political thought which concerned economic issues was also becoming more radical. Young Legionaries demanded, among others, introduction of tripartite economy (individual, socialized, state), the ban on foreign capital inflow, the interference of state into foreign trade, the abolition of trade secrets and the reconstruction of the agricultural system. Officially, however, the LY supported government actions.

Another important document, which is essential for the analysis of LY political thought, was the third ideological declaration of 1935 which mitigated the provisions of the previous one. For example, there disappeared the entries concerning total nationalization of the economy and opposition to the institution of the Catholic Church, in favor of a partial nationalization and the pursuance to provide every citizen with as far-reaching freedom of conscience and tolerance as possible. 
Legion of the Young failed to put the declared ideological assumptions into practice, but its political thought influenced the foundations of ideological and political declaration of Camp of National Unity, which allows the assertion that, contrary to critical evaluation, it was not just worthless chatter of academics.

Keywords: Legion of the Young, youth organizations, Piłsudski Camp, political thought, Second Polish Republic

DOI:10.7862/rz.2015.hss.25

Przesłano do redakcji: listopad 2014

Przyjęto do druku: lipiec 2015 